Hydrol. Earth Syst. Sci. Discuss., 6, 1385-1409, 2009 www.hydrol-earth-syst-sci-discuss.net/6/1385/2009/ (C) Author(s) 2009. This work is distributed under the Creative Commons Attribution 3.0 License.
Hydrology and Earth System Sciences Discussions

Papers published in Hydrology and Earth System Sciences Discussions are under open-access review for the journal Hydrology and Earth System Sciences

\title{
Dryness/wetness variations in China during the first 50 years of the 21st century
}

J. Q. Zhai ${ }^{1,5}$, B. Liu ${ }^{1,5}$, H. Hartmann ${ }^{3}$, B. D. Su ${ }^{2}$, T. Jiang ${ }^{1,2}$, and K. Fraedrich ${ }^{4}$

${ }^{1}$ State Key Laboratory of Lake Science and Environment, Nanjing Institute of Geography and Limnology, Chinese Academy of Sciences, Nanjing 210008, China

${ }^{2}$ Centre on Climate Change, China Meteorological Administration, Beijing 100081, China

${ }^{3}$ Department of Geography, Justus Liebig University, Giessen, Germany

${ }^{4}$ Meteorological Institute, Hamburg University, Hamburg, Germany

${ }^{5}$ Graduate University of Chinese Academy of Sciences, Beijing 100049, China

Received: 25 December 2008 - Accepted: 9 January 2009 - Published: 2 March 2009

Correspondence to: J. Q. Zhai (jianqing9801@163.com)

Published by Copernicus Publications on behalf of the European Geosciences Union.

\section{HESSD}

$6,1385-1409,2009$

Dryness/wetness variations in China

J. Q. Zhai et al.

Title Page

Abstract

Introduction

Conclusions

References

Tables

Figures

14

I

4

Back

Close
Printer-friendly Version

Interactive Discussion 


\section{Abstract}

This study investigates future changes of dryness/wetness in China during the first 50 years of the 21 st century according to the Standardized Precipitation Index (SPI), which is calculated by monthly precipitation data of ECHAM5/MPI-OM. Three anthro5 pogenic greenhouse gas emission scenarios SRES-A2, SRES-A1B and SRES-B1 have been considered. The frequency of dry/wet periods in ten river basins is counted and the trend is analyzed and detected by a linear regression model and the MannKendall non-parametric test. The results reveal that there is a trend towards drier conditions from Northeast to Southwest China in scenario A2 and a similar spatial distribution pattern in scenario A1B and B1. Areas with a high frequency of drought are detected under three scenarios. In the next half century, the Haihe River basin is expected to show a significant trend towards drier conditions, which pass the $95 \%$ confidence level in scenario A2. In the Yellow River basin, the Huaihe River basin, the Yangtze River basin and the Pearl River basin an obvious trend towards wetter conditions has been detected in scenario A1B. The Songhuajiang River basin, the Haihe River basin, the Yellow River basin and the Huaihe River basin show a trend towards wetter conditions, which passed the $90 \%$ confidence level in scenario B1. In addition, a decadal variation of dryness/wetness is projected for all the river basins.

\section{Introduction}

20 Warming of the climate system is unequivocal, as is now evident from observations of increases in global average air temperature. There is also observational evidence from all continents and most oceans that many natural systems are affected by regional climate changes (IPCC, 2007). Under the background of global climate change, it is one of the most important frontier fields of presently global change research to

25 study the changing characteristics of regional climate. Drought is one of the major natural hazards that bring about billions of dollars in loss to the agricultural commu-
HESSD

$6,1385-1409,2009$

\section{Dryness/wetness variations in China}

J. Q. Zhai et al.

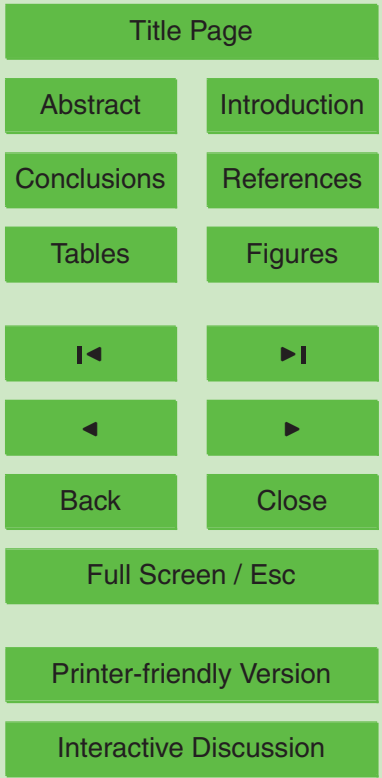

Interactive Discussion 
nity of the world every year (Narasimha and Srinivasan, 2005; Su et al., 2007). Bordi and Sutera (2002) presented a study on the drought occurrence in Italy based on the NCEP/NCAR reanalysis precipitation rates covering the period from 1948 to 2000 . They implied that drought conditions have been more frequent and extended in the 5 recent past. Li et al. (2004) analyzed the change trend of the Palmer Drought Severity Index and the possible response of the drought change rate to global warming in the main arid regions of the world for the recent hundred-odd years by using global grids of $2.5^{\circ} \times 2.5^{\circ}$. The results showed that there is an obvious trend towards drier conditions in the main arid regions of South America, South Africa, North America, Central Asia 10 and Northwest China.

It is also important to analyze the variation of dryness/wetness in China. Many studies have been conducted regarding to climate drought in China in the past years. Li et al. (1996) drew a conclusion that there were four large drought centers in China and there was a linear tendency of drying in the whole country and in most areas. Zhai and Zou (2005) analyzed the characteristics of drought in China during 1951 to 2003 according to the data of 606 meteorological stations. They pointed out that precipitation was the most important factor for drought changes. In the past fifty years, areas of drought had an increasing trend while this trend is not significant. Ma and Ren (2007) analyzed the relationship between climate change and a trend towards drier conditions based on the monthly mean surface air temperature and monthly precipitation data of 160 meteorological stations over China from 1951 to 2006. They found that there were trends towards drier conditions in North China, Northeast China, the east part of Northwest China, and Southwest China. Phase and duration of the drying processes would be different in the above mentioned regions. Many other researches detected

25 a trend towards drier conditions in North China and Northeast China in the past fifty years (Zhang, 1998; Xie et al., 2003; Wang and Zhai, 2003; Wei, 2004; Bordi et al., 2004). All of these studies concentrate on the variation of dryness/wetness in the past. Now, this study is subject to an objective drought assessment of China during the first fifty years of the 21 st century.

\section{HESSD}

6, 1385-1409, 2009

\section{Dryness/wetness variations in China}

J. Q. Zhai et al.

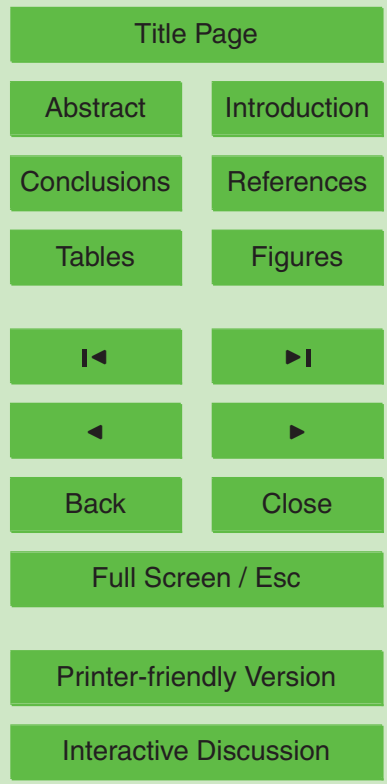

Interactive Discussion

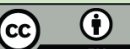


The aim of this study is to apply the SPI in order to indentify dry/wet periods during the first fifty years of the 21st century in China. Data and analytical methods, which are used in this study, are described in Sect. 2. In Sect. 3 the simulation ability of the ECHAM5 model is tested on annual averaged precipitation. The results of cal5 culating the SPI derived from the monthly precipitation data of the three scenarios of ECHAM5/MPI-OM and the analysis of dryness/wetness in China are shown in Sect. 4. Discussion and conclusions are presented in Sect. 5.

This study will help to understand variations of water resources in the future fifty years in China.

\section{Study area, data and methods}

\subsection{Study area and data}

China is divided into ten large river basins i.e. the Songhuajiang River basin, the Liaohe River basin, the Haihe River basin, the Yellow River basin, the Huaihe River basin, the Yangtze River basin, the Pearl River basin, the Southeast River basins, the Southwest

River basins (Fig. 1). Because of spanning many degrees of latitude and complicated terrain, climate of China varies sharply. Annual averaged precipitation gradually decreases from Southeast China to Northwest China. Due to the uneven distribution of precipitation for different regions and different seasons, droughts and floods occur frequently.

Considering the data quality, continuity, homogeneity and the length of data record, monthly precipitation of 483 meteorological stations (1960.01-2000.12) were provided by the National Climate Center of China Meteorological Administration, which is used to test and verify the simulate ability of ECHAM5 Model. Monthly precipitation data (2001.01-2050.12) of three scenarios (SRES-A2, SRES-A1B and SRES-B1) from simulations with the GCM ECHAM5/MPI-OM were used for the calculation of the SPI. The ECHAM5 data were provided by the Max Planck Institute for Meteorology (MPIM). The
HESSD

$6,1385-1409,2009$

\section{Dryness/wetness variations in China}

J. Q. Zhai et al.

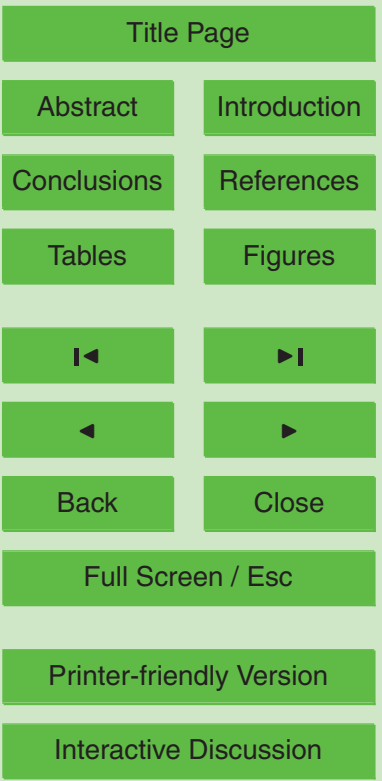


resolution of the atmospheric model ECHAM5 is triangular T63 $\left(1.875^{\circ} \times 1.875^{\circ}\right)$ with 31 vertical levels. The atmospheric model is coupled with the ocean model MPI-OM with $1.5^{\circ}$ resolution without flux correlation (Blender and Fraedrich, 2006).

\subsection{Methods}

5 The nature of SPI allows comparing the frequency of dry/wet periods among the regions with different climate and water supplies. It can measure how much precipitation for a certain time period has deviated from historically established norms. The categorization of the dryness/wetness grade by the SPI is given in Table 1 (McKee et al., 1993).

10 The SPI was developed by McKee et al. (1993) for the identification of dry/wet periods and to evaluate their severity (Moreira et al., 2006). The calculation of the SPI can be based on a long-term precipitation record for any location (Hayes et al., 1999). This long-term precipitation record is fitted to a gamma distribution at first. Then, the cumulative probability of an observational precipitation event for each time scale of in15 terest would be deduced. The value of the SPI can be obtained by transforming the cumulative probability to a standard normal random variable with zero mean and a variance of one. Positive variables indicate greater than median precipitation, and negative variables indicate less than median precipitation, with values ranging from about -3 to 3 . This study is based on the Standardized Precipitation Index (SPI, introduced 20 by McKee et al., 1993). As the SPI characterizes water deficit and surplus, derived from precipitation alone, it can be easily computed and as the index is standardized, it is also suitable for comparing different regions or water-sheds (Bordi et al., 2004).

The trend tests applied in this study are the non-parametric Mann-Kendall test and the simple linear regression method. Mann-Kendall analysis is a rank-based procedure 25 suitable for detecting non-linear trends. More details can be found in the previous studies (Mann, 1945; Kendall, 1975).

The inverse distance weighted interpolation method is used to detect the spatial distribution of drought.

\section{HESSD}

$6,1385-1409,2009$

\section{Dryness/wetness variations in China}

J. Q. Zhai et al.

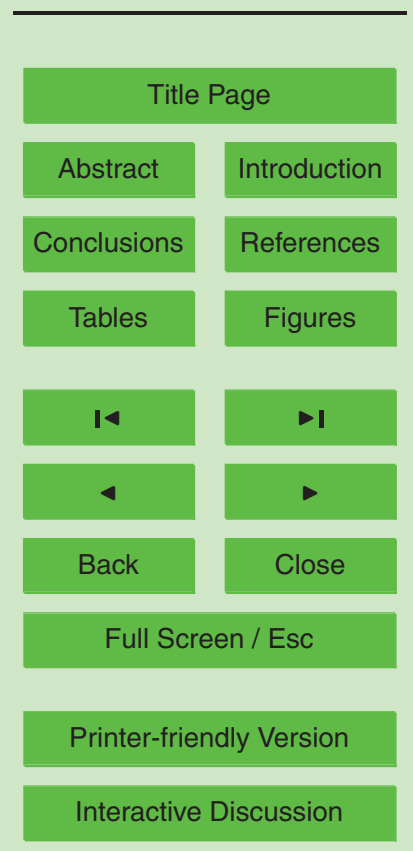


In this paper, SPI was calculated at the 12-monthly time scale at every grid. The month with the value of SPI less than -1 was counted in every grid. Then the areas more than 100 dry months were detected in the figure which was interpolated with IDW method. Linear trend was calculated in every grid. Spatial patterns of trend of dry/wet 5 could be detected in the figure. At last, spatial averaged SPI was calculated in ten large river basins and change of years about dry/wet was analyzed.

\section{Test of the precipitation simulation ability of the ECHAM5 Model in China}

Annual averaged precipitation and precipitation anomaly are calculated not only based on observational monthly precipitation derived from 483 meteorological stations but 10 also according to monthly rainfall which is simulated by ECHAM5 model in China during 1961-2000. The results indicate that there is a decreasing trend from Southeast China to Northwest China with annual precipitation ranges from over $1600 \mathrm{~mm}$ to less than $50 \mathrm{~mm}$ both for observational and projected annual averaged precipitation, although the magnitude of the projected means annual precipitation is more than that of 15 the observational rainfall (Fig. 2). Precipitation anomaly also indicates that the annual changing trend is different before 1980 but coincident between observational precipitation and projected rainfall during 1980-2000 (Fig. 3). All in all, the ECHAM5 model roughly simulated the spatial distribution and decreasing and increasing trends of annual averaged precipitation in China. So it is some useful to project the character of
HESSD

$6,1385-1409,2009$

\section{Dryness/wetness variations in China}

J. Q. Zhai et al.

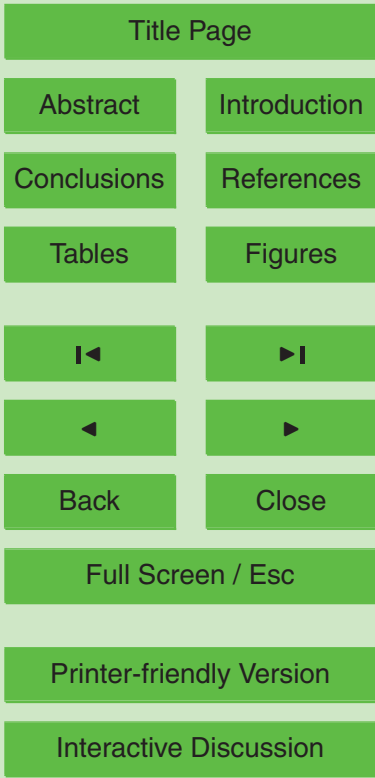

The number of months, which have been classified as drought months regarding the $\mathrm{SPI}(\mathrm{SPI} \leq-1)$, is counted for the three scenarios for the first 50 years of the $21 \mathrm{st}$ 
century. In the scenario A2, one high value area exists in North China with more than 100 dry months during 2002-2050. This region includes the Songhuajiang River basin, the north part of the Liaohe and Yellow River basins, and some areas of the Northwest River basins. In addition, two high value centers are located in the Jinshajiang River 5 catchment and the Hanjiang river catchment. There are two high value areas with more than 100 dry months in the eastern part of the Huaihe River basin and the south part of the Pearl River basin (Fig. 4a). Figure 4b shows that other high value areas are located in the Songhuajiang River basin, the south part of Yellow River basin, the Jinshajiang River catchment, the Pearl River basin, the Southwest River basins and some parts of 10 Northwest River basins in the scenario A1B. In the scenario B1, the areas with high frequency of dryness may include the Haihe River basin, the east part of Yellow River basin, the Dongting lake catchment of the Yangtze River basin, the Southeast River basins and some parts of Northwest River basins (Fig. 4c).

\subsection{Trend analysis of dryness/wetness}

15 The spatial distribution of the linear trend of every grid cell is shown in Fig. 5. The positive and negative trends, which represent trends towards wetter and drier conditions, are detected.

It is known from the trends of the SPI index that there is a negative trend from Northeast to Southwest China which covers the Songhuajiang River basin, the Liaohe River 20 basin, the Haihe River basin, the Yellow River basin, the south part of Jianshajiang River catchment of the Yangtze River basin and the west part of Pearl River basin in the scenario A2 (Fig. 5a). But positive trends dominate in the northwest and the southeast of China, including the northwest parts of the Inland River basins, the middle and lower Yangtze River basin and the Southeast River basins (Fig. 5a). This situation is 25 similar with the observational trend during 1961-2005. Figure 5b indicates a different spatial distribution; the area covered by a negative trend is greatly reduced. The trend towards drier conditions only occurs in the Liaohe River basin, the River source basin of the Yellow River and the Yangtze River, the Southwest River basins and the northwest

\section{HESSD}

$6,1385-1409,2009$

\section{Dryness/wetness variations in China}

J. Q. Zhai et al.

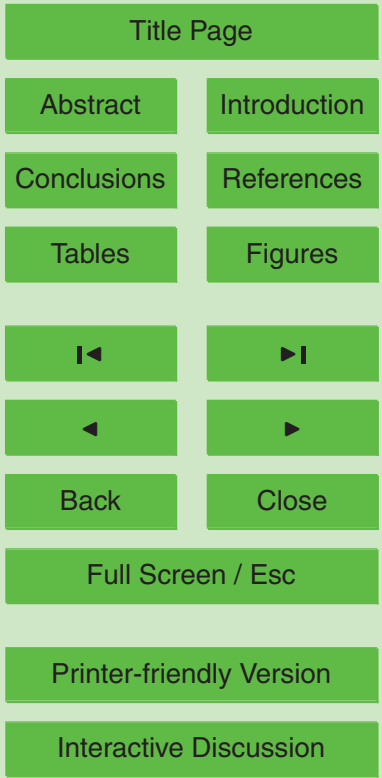


part of the Northwest River basins. In some regions of the Dongting lake catchment and the Yangtze estuary a negative trend can be detected. The trends in scenario B1 have shown a similar spatial distribution pattern with those of Scenario A1B, as was illustrated in Fig. 5c. The areas showing significant trends towards drier conditions are 5 still located in Northwest China and the upper reaches of the Yellow River, the Yangtze River and the Southwest Rivers. The main difference between the Fig. $5 b$ and $c$ is that the most parts of South China show an obvious trend towards drier conditions in scenario B1.

\subsection{Change of dryness/wetness in all large river basins}

10 Basin averaged SPI are calculated and their trends are tested by the Mann-Kendall non-parametric method. Table 2 shows that only in the Haihe River basin a significant trend towards drier conditions can be detected, which pass the $95 \%$ confidence level in the scenario A2. The trend towards wetter conditions passed the $90 \%$ confidence level in the Yellow River basin (99\% confidence level), the Huaihe River basin, the Yangtze River basin (95\% confidence level) and the Pearl River basin (99\% confidence level) in scenario A1B. Similar trends towards wetter conditions occur in the Songhuajiang River basin, the Haihe River basin, the Yellow River basin and the Huaihe River basin in scenario B1 (Table 2).

Based on monthly averaged basin-wide SPIs (Figs. 6, 7, 8), in scenario A2, there are three stages in the Songhuajiang River basin during 2002-2050 (Fig. 6a): a trend towards wetter conditions during 2002-2022; a trend towards drier conditions during 2022-2040; another wetness stage from 2040-2050. An slowly wetter period exist in the Liaohe River basin during 2002-2022; then the period from 2022 to 2038 is a dryness stage; at last, a dryness period begins in 2040 and ends in 2048 (Fig. 6b). In

the Haihe River basin, there is a ten years period which is alternative between dryness and wetness (Fig. 6c). There is a dry period from 2022-2040 in the Yellow River basin (Fig. 6d). It is a almost same dryness period in South China including the Huaihe River basin, the Yangtze River basin, the Pearl River basin and the Southeast River basins

HESSD

$6,1385-1409,2009$

\section{Dryness/wetness variations in China}

J. Q. Zhai et al.

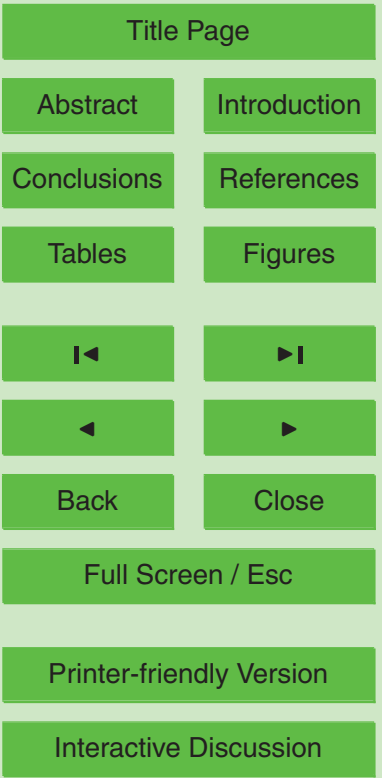

Interactive Discussion 
in 2010s, 2020s, 2030s (Fig. 6e-h). Wet period begins from 2030 in the Southwest River basin (Fig. 6i). It is almost wet period before 2030 in the Northwest River basin (Fig. 6j).

Figure 7 shows the change of dryness/wetness in ten large river basins in the sce5 nario A1B. There are not obviously changes of dryness/wetness in almost every river basin. In the 2030s and the 2040s, a dryness stage exists in the Haihe River basin (Fig. 7c). In the Yellow River basin, there is a dryness period from 2002-2020 (Fig. 7d). There is a dry period in the Huaihe River basin in the 2030s (Fig. 7e). In the Pearl River basin is a dry period (Fig. $7 \mathrm{~g}$ ).

10 Figure 8 indicates the change rules of dryness/wetness in ten large river basins in the scenario B1. An obvious dry period occurs in the Songhuajiang River basin and the Liaohe River basin in the 2010s (Fig. 8a, b), and in the Haihe River basin during 2006-2012 (Fig. 8c), the Yellow River basin in the 2020s, and the 2030s (Fig. 8d), and in the Pearl River basin in the 2020s, and the 2040s (Fig. 8g).

\section{Summary and conclusions}

Drought exerts tremendous influences on agriculture and human society. Characteristics of dryness/wetness in three scenarios (A2, A1B and B1) were analyzed in this study based on the SPI, which was calculated based on the monthly precipitation data derived from ECHAM5/MPI-OM. Some results are summed up as follows.

The areas with high frequency drought differ for the three scenarios in China during 2002-2050. In scenario A2, an arid zone exists in North China including the Songhuajiang River basin, the Liaohe River basin, the north of the Yellow River basin and most parts of the Northwest River basins. High values were also found in the Huaihe River basin, the Jingshajiang River catchment and the Hanjiang River catchment of the Yangtze River basin and the Pearl River basin. In scenario A1B, high value regions with over 100 dry months are located in the Songhuajiang River basin, the south of the Yellow River basin, the upper river of the Yangtze River and the Southwest River

HESSD

$6,1385-1409,2009$

\section{Dryness/wetness variations in China}

J. Q. Zhai et al.

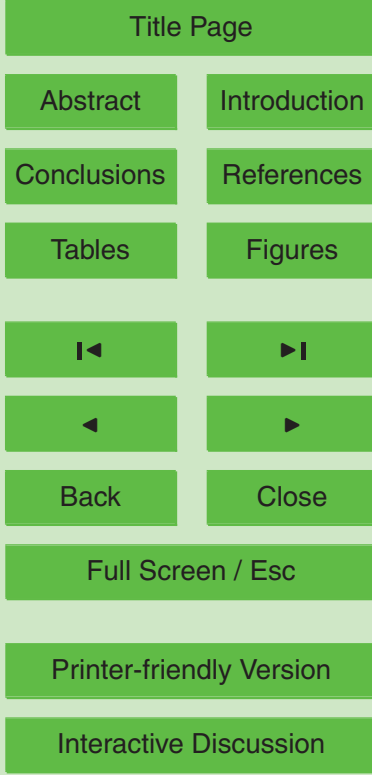


basins. However, just the Haihe River basin, the east parts of the Yellow River basin and the Southeast River basin show a high frequency of droughts.

A negative trend (trend towards drier conditions) was found from northeast to southwest of China including the Songhuajiang River basin, the Liaohe River basin, the 5 Haihe River basin, the Yellow River basin, the upper reach of the Yangtze River and the west part of the Pearl River basin in the scenario A2. While in the scenario A1B, a negative trend only exists in the Liaohe River basin, the Southwest River basins and in the south part of the Northwest River basins. A similar spatial distribution pattern is found in the scenario B1. The main difference is that a trend towards drier conditions occurs in most parts of South China.

By analyzing monthly SPIs, different dry periods can be found in the ten large river basins for the future 50 years.

Although ECHAM5/MPI-OM can simulate the precipitation in China, the uncertainty should be paid attention.

15 Acknowledgements. The work is financially supported by the National Science Foundation of China (project no. 40601017, 40771040, 40701028). Mutual visits of the partners have been sponsored by the Sino-German Center for Research Promotion (GZ 412). The authors are very grateful to these institutions for their financial support. Moreover, the authors express their thanks to the National Climate Centre (NCC) of China Meteorological Administration (CMA) 20 and the Potsdam Institute for Climate Impact Research for providing software to calculating SPI.

\section{References}

Bordi, I. and Sutera, A.: An analysis of drought in Italy in the last fifty years, IL Nuovo Cimento, 25C, 185-206, 2002.

25 Bordi, I., Fraedrich, K., Jiang, J. M., and Sutera, A.: Spatio-temporal variability of dry and wet periods in eastern China, Theor. Appl. Climatol., 79, 81-91, doi:10.1007/s00704-004-00538, 2004.

\section{HESSD}

6, 1385-1409, 2009

\section{Dryness/wetness variations in China}

J. Q. Zhai et al.

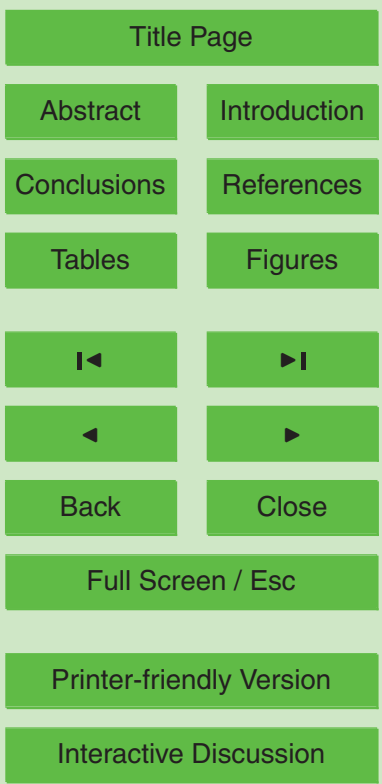


Blender, R. and Fraedrich, K.: Long-term memory of the hydrological cycle and river runoffs in China in a high-resolution climate model, Int. J. Climatol., 26, 1547-1565, doi:10.1002/joc.1325, 2006.

Hayes, M. J., Svoboda, M. D., Wilhite, D. A., and Vanyarkho, O. V.: Monitoring the 1996 Drought Using the Standardized Precipitation Index, B. Am. Meteorol. Soc., 80(3), 429-438, 1999.

IPCC: Climate change 2007: the AR4 Synthesis Report, online available at: http://www.ipcc. $\mathrm{ch}$ /, published by IPCC, Geneva, Switzerland, 2007.

Kendall, M. G.: Rank Correlation Methods, Charles Griffin, London, UK, 202 pp., 1975.

Li, K. R., Yin, S. M., and Sha, W. Y.: Characteristics of Time-Space of Recent Drought in China, 10 Geogr. Res., 15(3), 6-15, 1996.

Li, X. Z., Liu, X. D., and Ma, Z. G.: Analysis on the Drought Characteristics in the Main Arid Regions in the World since Recent Hundred-odd Years, Arid Zone Research, 21(2), 97-103, 2004.

Mann, H. B.: Non-parametric test against trend, Econometrica, 13, 245-259, 1945.

Mckee, T. B., Doesken, N. J., and Kleist, J.: The relationship of drought frequency and duration to time scales, Eighth Conference on Applied Climatology, 17-22, 1993.

Moreira, E. E., Paulo, A. A., Pereira, L. S., and Mexia, J. T.: Analysis of SPI drought class transitions using loglinear models, J. Hydrol., 331, 349-359, 2006.

Ma, Z. G. and Ren, X. B.: Drying Trend over China from 1951 to 2006, Advances in Climate $20 \quad$ Change Research, 3(4), 195-201, 2007.

Narasimhan, B. and Srinivasan, R.: Development and evaluation of Soil Moisture Deficit Index (SMDI) and Evapotranspiration Deficit Index (ETDI) for agricultural drought monitoring, Agr. Forest Meteorol., 133, 69-88, 2005.

Su, B. D., Gemmer, M., Jiang, T., and Ren, G. Y.: Probability Distribution of Precipitation Extremes over the Yangtze River Basin during 1960-2005, Advances in Climate Change Research, 3(4), 208-213, 2007.

Wang, Z. W. and Zhai, P. M.: Climate Change in Drought over Northern China during 19502000, ACTA Geographica Sinica, 58 (supplement), 61-68, 2003.

Wei, F. Y.: Characterization of drought strength in North China and its climatic variation. J. Natural Disasters, 13(2), 32-38, 2004.

Xie, A., Sun, Y. G., and Bai, R. H.: Arid Climate Trend over Northeastern China and Its Response to Global Warming, ACTA Geographica Sinica, 58 (supplement), 75-82, 2003.

Zhang, Q.: Research on Determination of Drought Index in North China and Its Application,
HESSD

6, 1385-1409, 2009

\section{Dryness/wetness variations in China}

J. Q. Zhai et al.

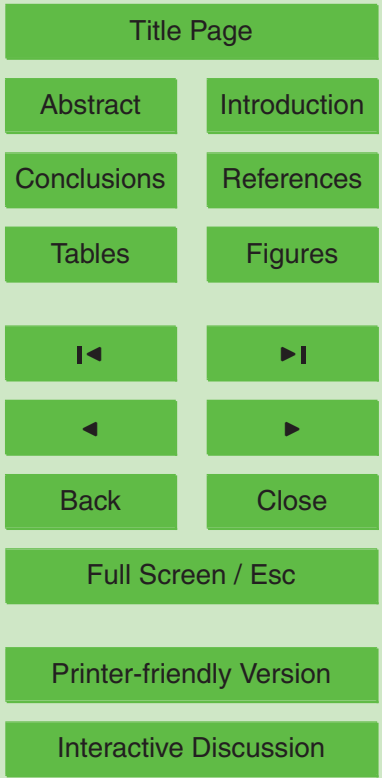


Journal of Catastrophology, 13(4), 34-38, 1998.

Zhai, P. M. and Zou, X. K.: Changes in Temperature and Precipitation and Their Impacts on Drought in China during 1951-2003, Adv. Clim. Change Res., 1(1), 16-18, 2005.

\section{HESSD}

$6,1385-1409,2009$

\section{Dryness/wetness variations in China}

J. Q. Zhai et al.

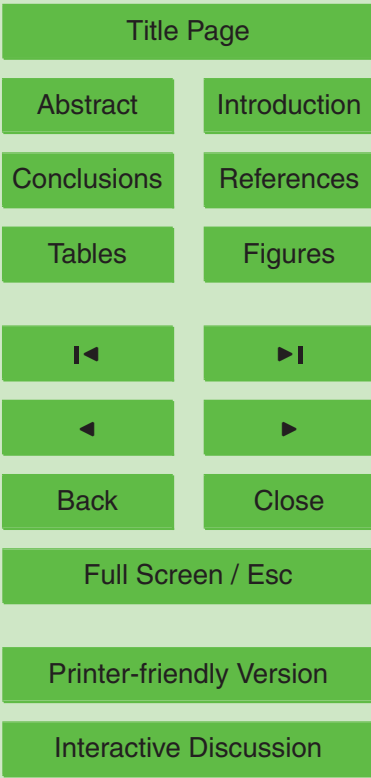




\section{HESSD}

$6,1385-1409,2009$

\section{Dryness/wetness} variations in China

J. Q. Zhai et al.

Table 1. Categorization of the dryness/wetness grade by the SPI.

\begin{tabular}{lc}
\hline Categories & SPI values \\
\hline extremely dryness & $\leq-2.0$ \\
severe dryness & $-1.99 \sim-1.5$ \\
moderate dryness & $-1.49 \sim-1.0$ \\
near normal & $-1.0 \sim 1.0$ \\
moderate wetness & $1.0 \sim 1.49$ \\
severe wetness & $1.5 \sim 1.99$ \\
extremely wetness & $\geq 2.0$ \\
\hline
\end{tabular}

Title Page

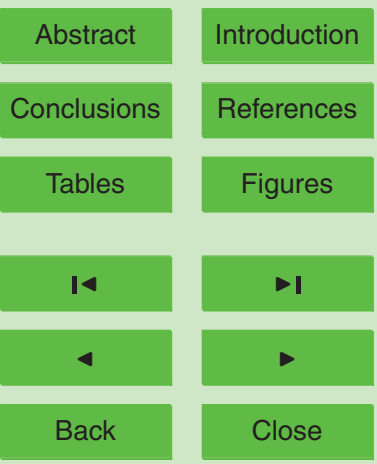

Full Screen / Esc

Printer-friendly Version

Interactive Discussion 


\section{HESSD}

$6,1385-1409,2009$

\section{Dryness/wetness variations in China}

J. Q. Zhai et al.

Table 2. Trend of dryness in ten large river basins of China during 2002-2050.

\begin{tabular}{lcccccccccc}
\hline Scenarios & $\begin{array}{c}\text { Songhuajiang } \\
\text { River } \\
\text { Basin }\end{array}$ & $\begin{array}{c}\text { Liaohe } \\
\text { River } \\
\text { Basin }\end{array}$ & $\begin{array}{c}\text { Haihe } \\
\text { River } \\
\text { Basin }\end{array}$ & $\begin{array}{c}\text { Yellow } \\
\text { River } \\
\text { Basin }\end{array}$ & $\begin{array}{c}\text { Huaihe } \\
\text { River } \\
\text { Basin }\end{array}$ & $\begin{array}{c}\text { Yangtze } \\
\text { River } \\
\text { Basin }\end{array}$ & $\begin{array}{c}\text { Pearl } \\
\text { River } \\
\text { Basin }\end{array}$ & $\begin{array}{c}\text { Southeast } \\
\text { River } \\
\text { Basins }\end{array}$ & $\begin{array}{c}\text { Southwest } \\
\text { River } \\
\text { Basins }\end{array}$ & $\begin{array}{c}\text { Northwest } \\
\text { River } \\
\text { Basins }\end{array}$ \\
\hline A2 & -0.33 & -0.84 & $-1.83^{* *}$ & -0.45 & 0.12 & 0.24 & -0.21 & 0.69 & 0.97 & 0.78 \\
A1B & 1.07 & 0.98 & 0.36 & $2.6^{* * *}$ & $1.29^{*}$ & $1.84^{* *}$ & $2.62^{* * *}$ & 0.78 & -0.34 & 0.72 \\
B1 & $1.5^{*}$ & 0.53 & $1.79^{* *}$ & $1.29^{*}$ & $2.64^{* *}$ & 0.36 & -0.59 & -0.55 & -0.41 & -0.38 \\
\hline
\end{tabular}

* denotes pass $90 \%$ confidence level;

** denotes pass $95 \%$ confidence level;

${ }^{\star * \star}$ denotes pass $99 \%$ confidence level.

Title Page

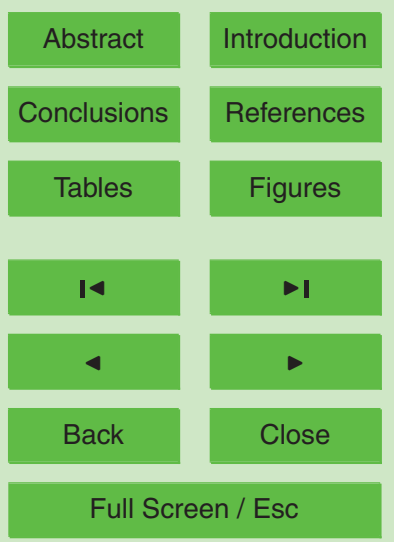

Printer-friendly Version

Interactive Discussion 
HESSD

6, 1385-1409, 2009

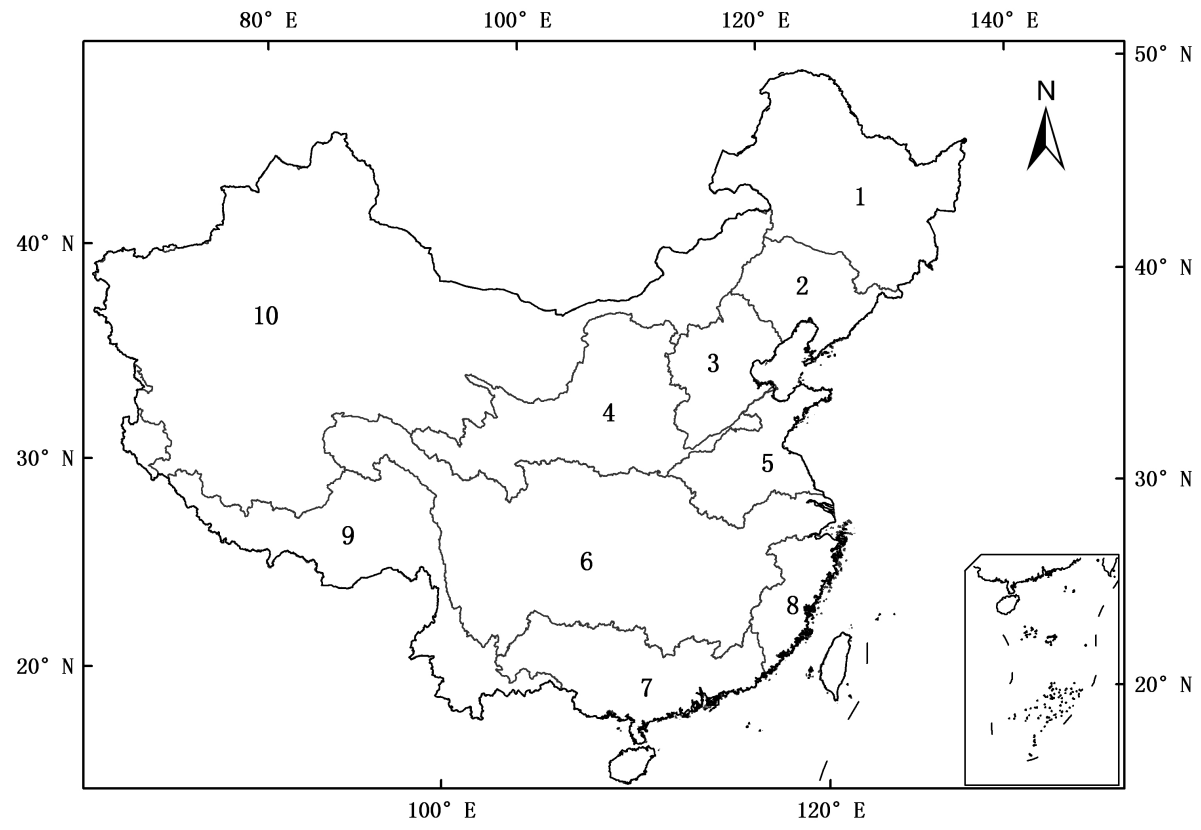

\section{Dryness/wetness variations in China}

J. Q. Zhai et al.

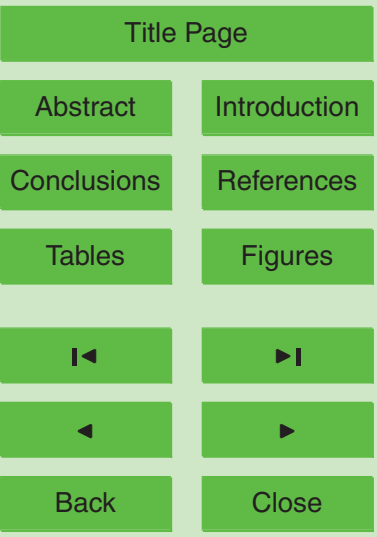

Full Screen / Esc

Printer-friendly Version

Interactive Discussion

Fig. 1. Ten large river basins in China. 


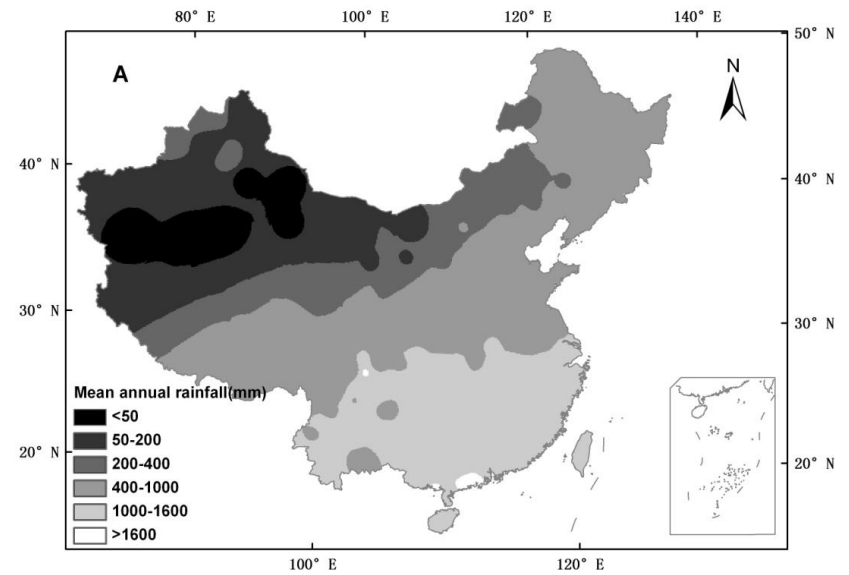

HESSD

$6,1385-1409,2009$

\section{Dryness/wetness variations in China}

J. Q. Zhai et al.

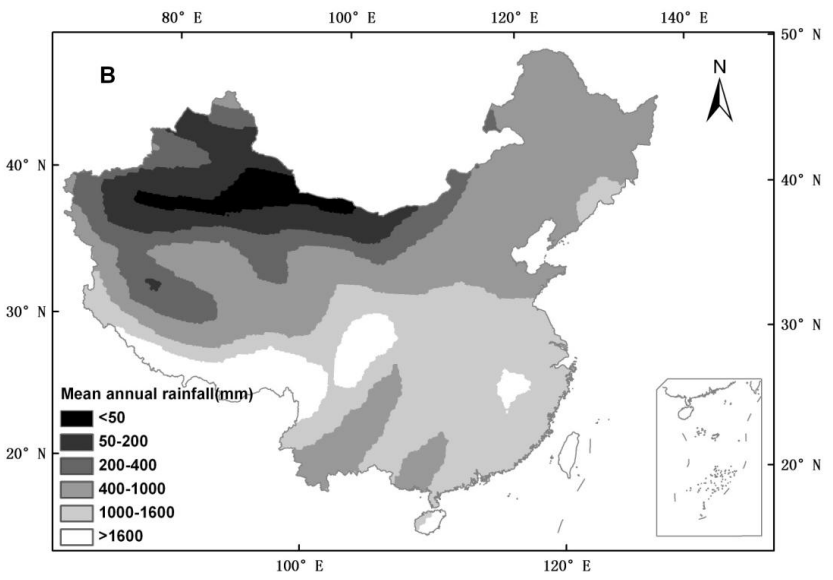

Title Page

\begin{tabular}{|c|c|}
\hline Abstract & Introduction \\
\hline Conclusions & References \\
\hline Tables & Figures \\
\hline I4 & \multicolumn{1}{|c|}{} \\
\hline 4 & \\
\hline Back & Close \\
\hline Full Screen / Esc \\
\hline
\end{tabular}

Printer-friendly Version

Interactive Discussion

Fig. 2. Spatial distribution of mean annual rainfall during 1961-2000 - (A) data from 483 observational meteorological stations; (B) data from ECHAM5 Model. 


\section{HESSD}

$6,1385-1409,2009$

\section{Dryness/wetness variations in China}

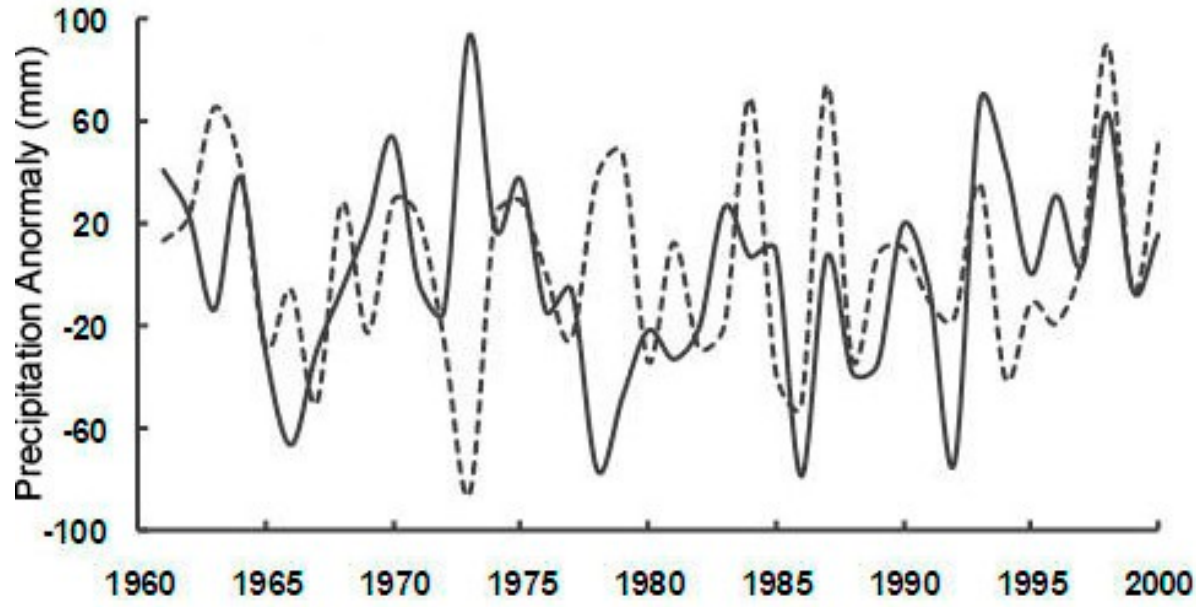

Fig. 3. Precipitation anomaly during 1961-2000 in China (dark line: precipitation from observational meteorological station; dotted line: precipitation from Echam5 Model).
J. Q. Zhai et al.

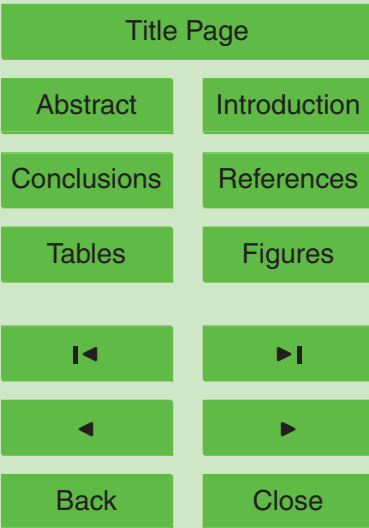

Full Screen / Esc

Printer-friendly Version

Interactive Discussion 


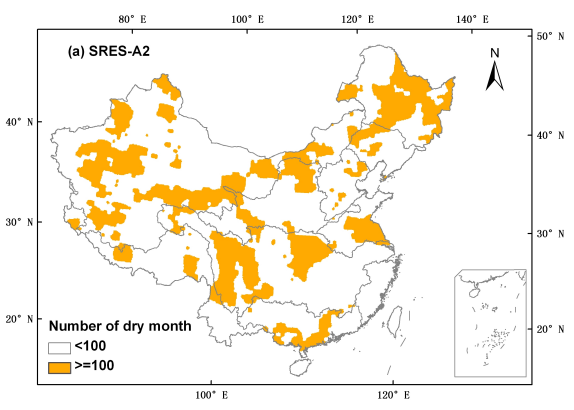

\section{HESSD}

6, 1385-1409, 2009

\section{Dryness/wetness variations in China}

J. Q. Zhai et al.

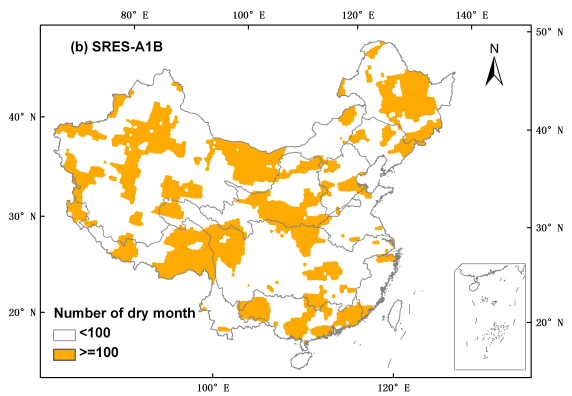

Title Page

\begin{tabular}{|c|c|}
\hline Abstract & Introduction \\
\hline Conclusions & References \\
\hline Tables & Figures \\
\hline I4 & \multicolumn{1}{|c|}{} \\
\hline 4 & \\
\hline Back & Close \\
\hline Full Screen / Esc
\end{tabular}

Printer-friendly Version

Interactive Discussion

Fig. 4. The number of all dry months during 2002-2050 (588 months). 


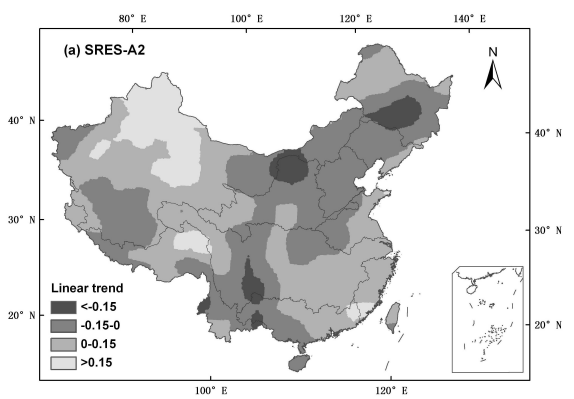

HESSD

$6,1385-1409,2009$

\section{Dryness/wetness variations in China}

J. Q. Zhai et al.

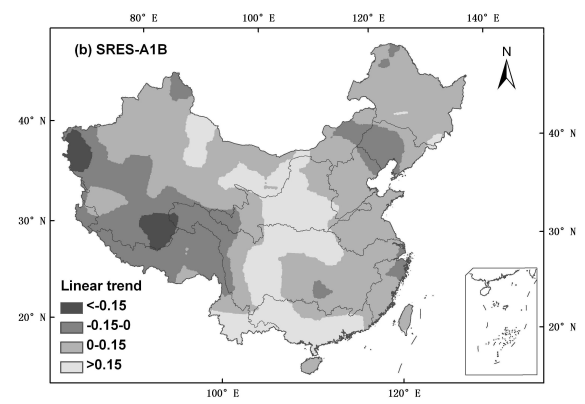

Title Page

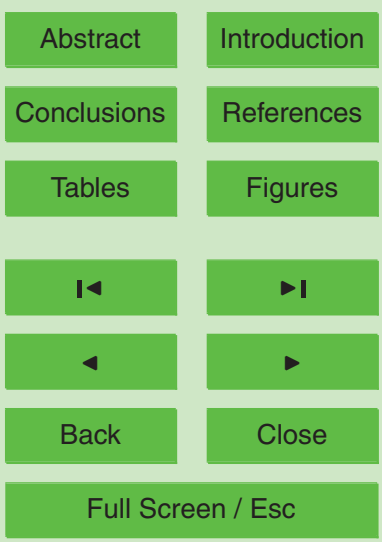

Printer-friendly Version

Interactive Discussion

Fig. 5. Spatial distribution of the trend of dryness/wetness in China during 2002-2050.

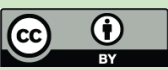




\section{HESSD}
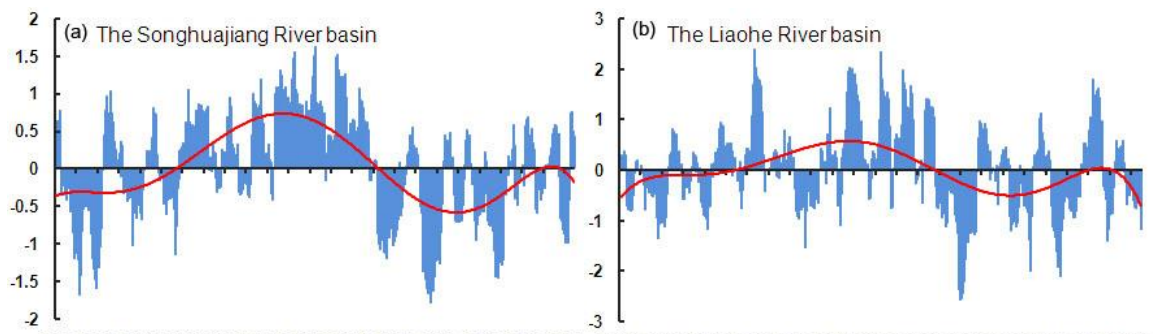

$6,1385-1409,2009$

20022006201020142018202220262030203420382042204620502002200620102014201820222026203020342038204220462050
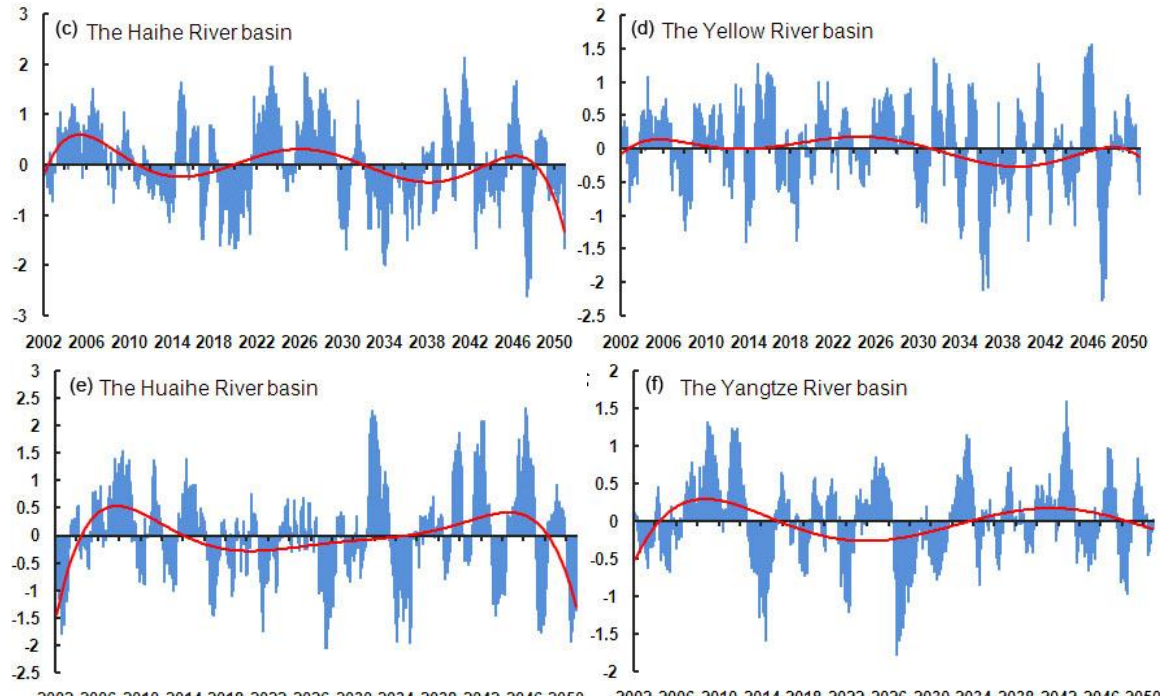

\section{Dryness/wetness variations in China}

J. Q. Zhai et al.

\section{Title Page}

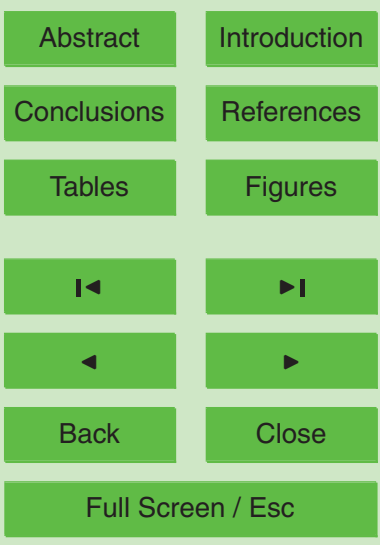

Printer-friendly Version

Interactive Discussion

Fig. 6. Variation of dryness/wetness in ten large river basins of China during 2002-2050 in scenario A2. 


\section{HESSD}

6, 1385-1409, 2009
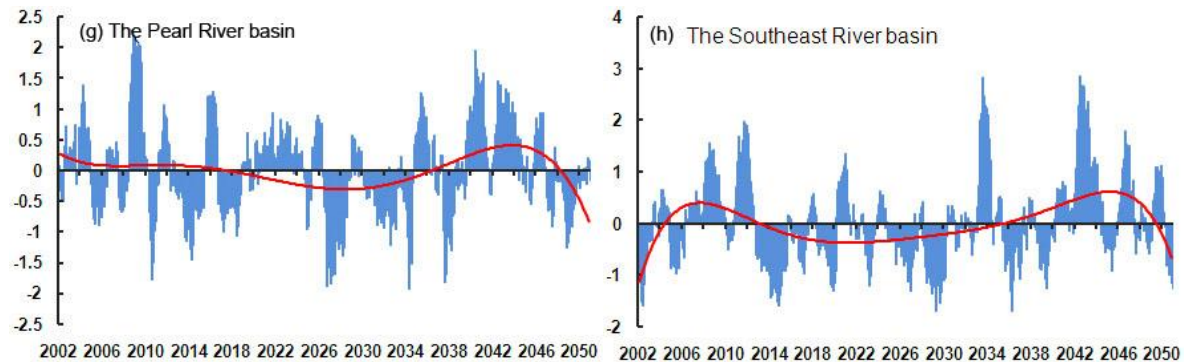

\section{Dryness/wetness variations in China}

J. Q. Zhai et al.

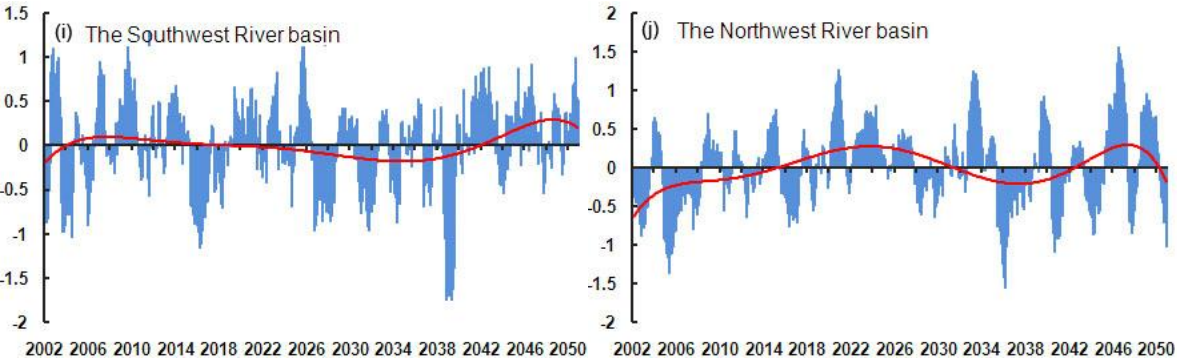

(n)

Title Page

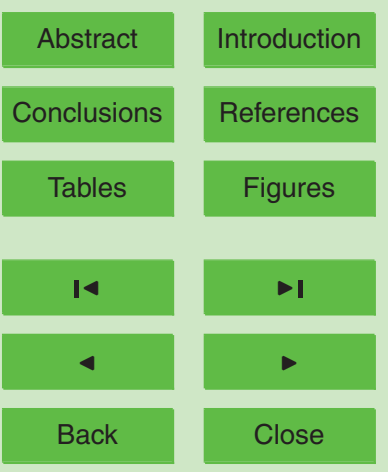

Full Screen / Esc

Fig. 6. Continued.

Printer-friendly Version

Interactive Discussion

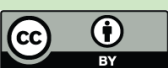




\section{HESSD}

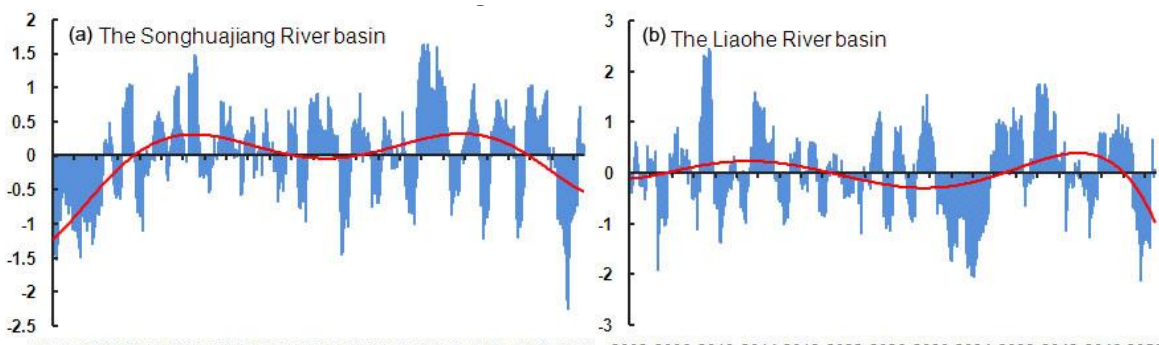

$6,1385-1409,2009$

\section{Dryness/wetness variations in China}

J. Q. Zhai et al.

20022006201020142018202220262030203420382042204620502002200620102014201820222026203020342038204220462050
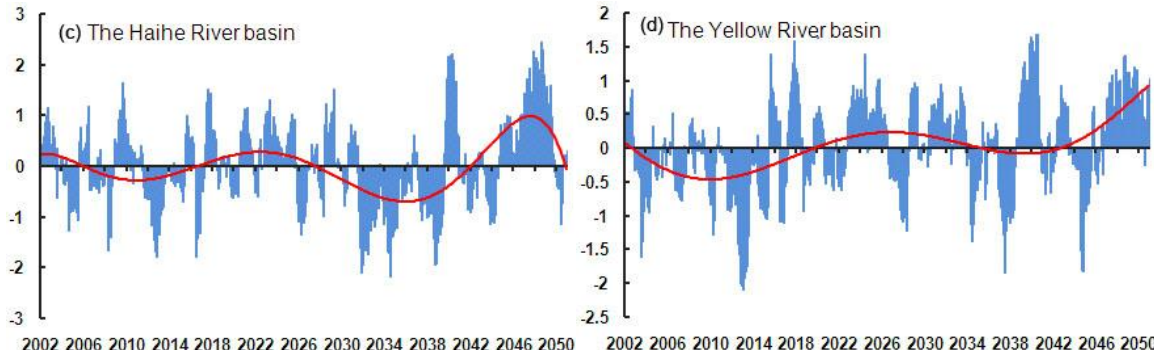

Title Page
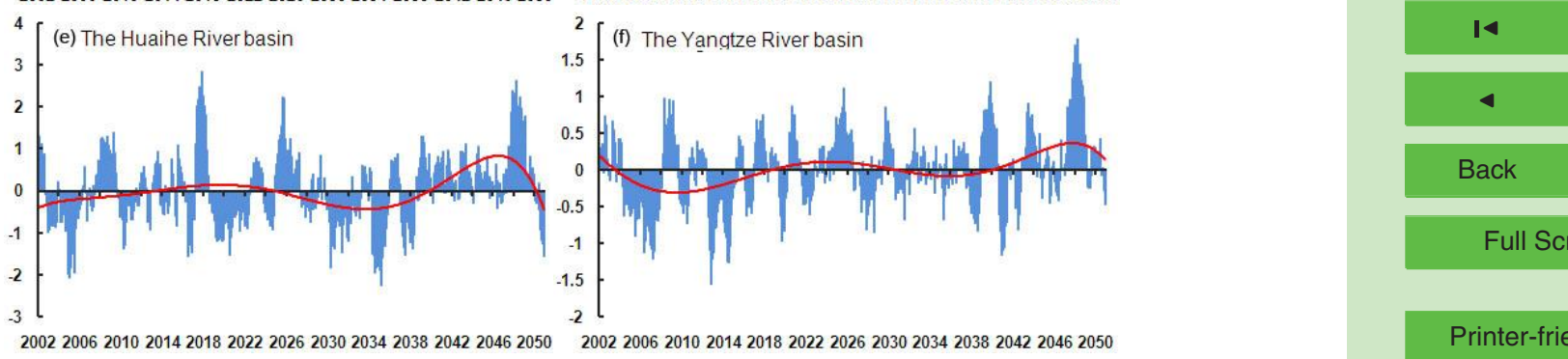

Full Screen / Esc

Printer-friendly Version

Fig. 7. Variation of dryness/wetness in ten large river basins of China during 2002-2050 in Interactive Discussion scenario A1B. 


\section{HESSD}

6, 1385-1409, 2009
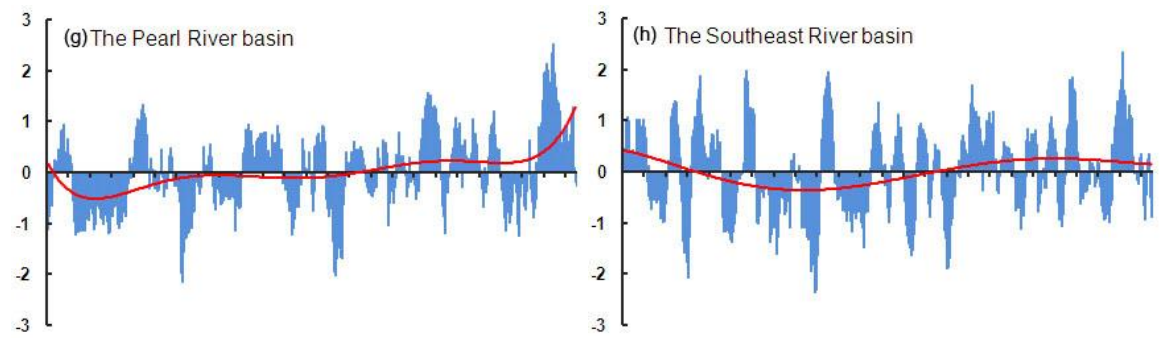

\section{Dryness/wetness variations in China}

20022006201020142018202220262030203420382042204620502002200620102014201820222026203020342038204220462050
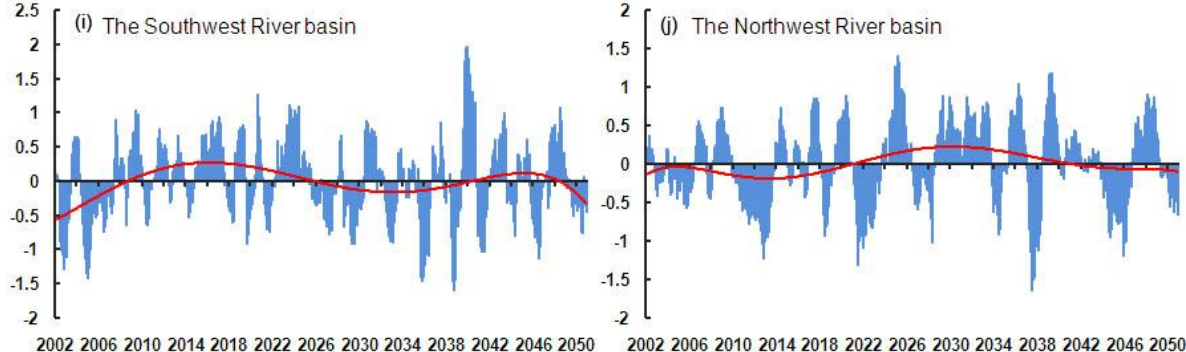

Fig. 7. Continued.

J. Q. Zhai et al.

Title Page

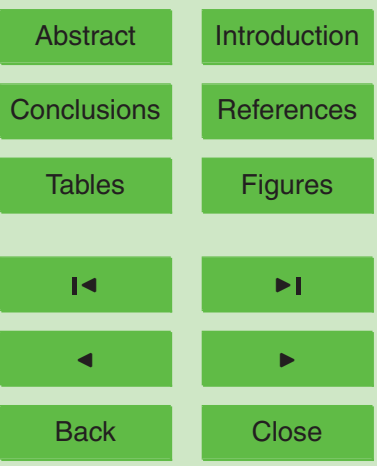

Full Screen / Esc

Printer-friendly Version

Interactive Discussion 

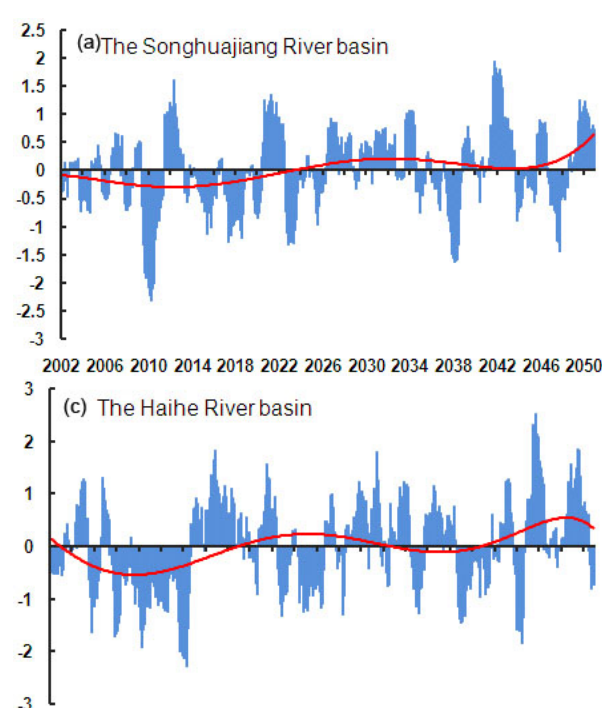

2002200620102014201820222026203020342038204220462050

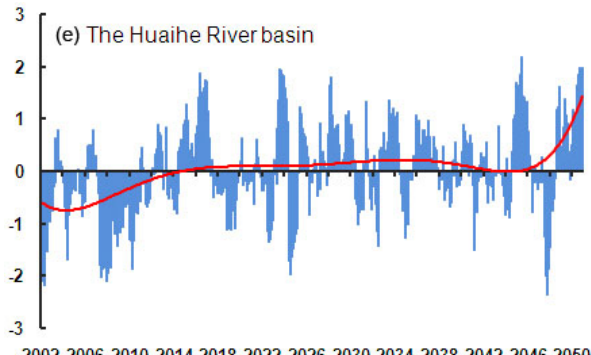

2002200620102014201820222026203020342038204220462050

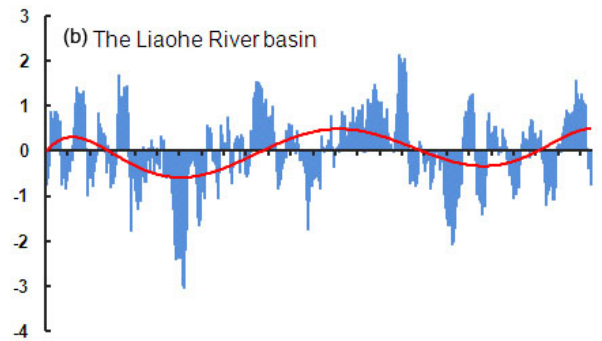

2002200620102014201820222026203020342038204220462050

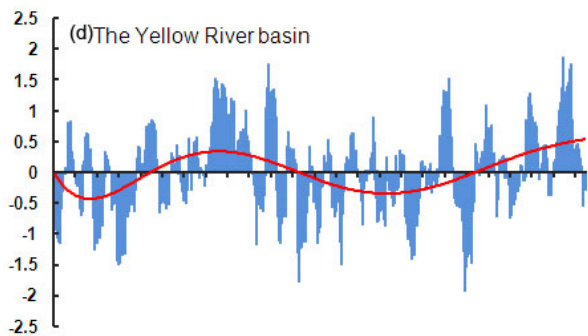

2002200620102014201820222026203020342038204220462050

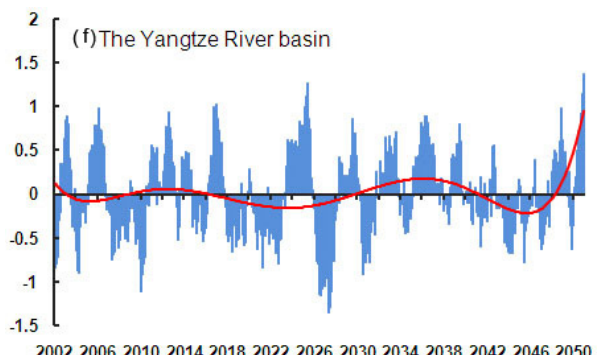

HESSD

$6,1385-1409,2009$

\section{Dryness/wetness variations in China}

J. Q. Zhai et al.

Title Page

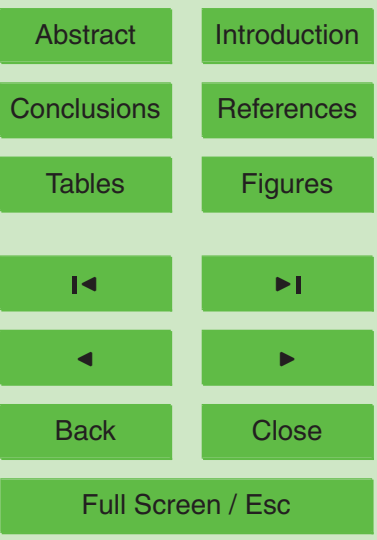

Printer-friendly Version

Interactive Discussion

Fig. 8. Variation of dryness/wetness in ten large river basins of China during 2002-2050 in scenario B1. 


\section{HESSD}

6, 1385-1409, 2009
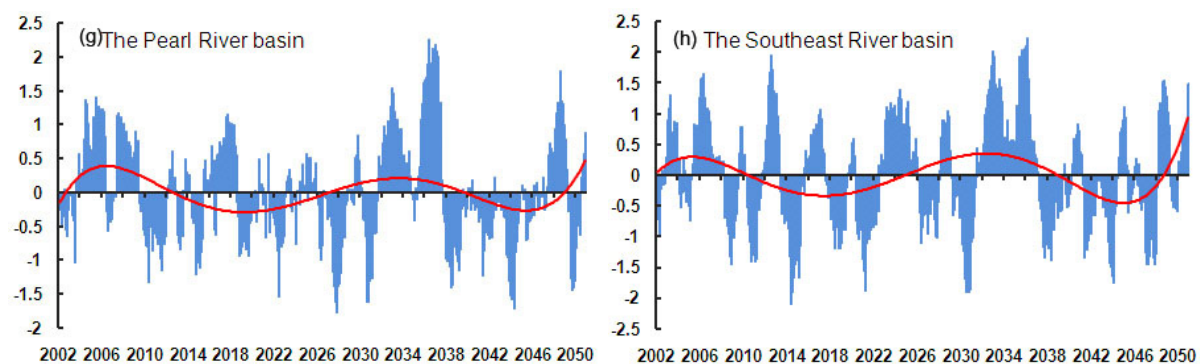

\section{Dryness/wetness variations in China}

J. Q. Zhai et al.
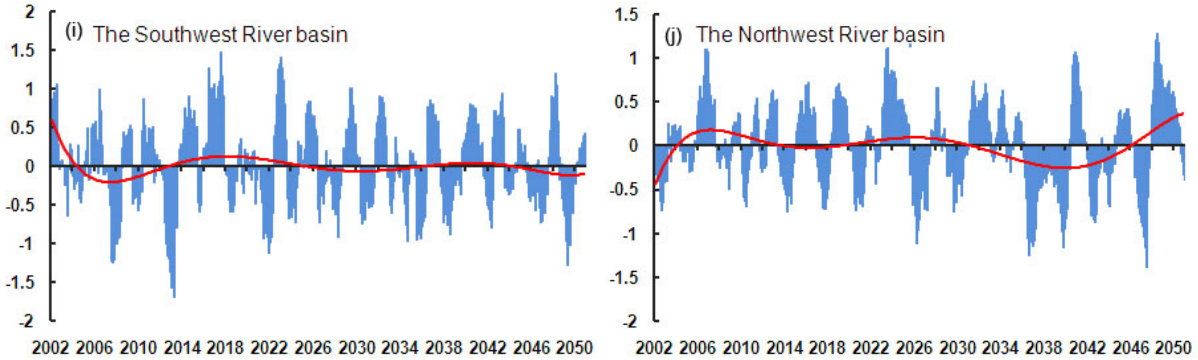

\section{Title Page}

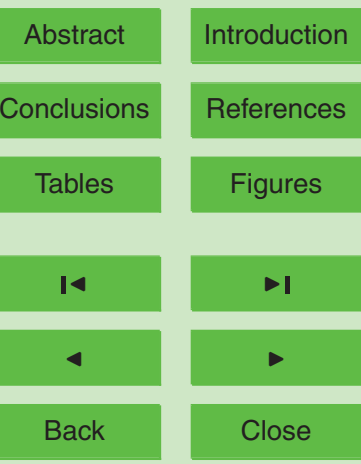

Full Screen / Esc

Fig. 8. Continued.

Printer-friendly Version

Interactive Discussion 